DOI https://doi.org/10.30525/978-9934-571-83-1-7

\title{
THE CORRELATION OF INTERNATIONAL TREATY INTERPRETATION WITH OTHER LEGAL INTERPRETATIONS
}

\section{Karvatska S. B.}

\section{INTRODUCTION}

Today international law is no longer an intergovernmental right, intended to join national interests. This is the right of the international community to guard the general supranational interests of mankind. In the historical context of international relations development, the second half of the $\mathrm{XX}^{\text {th }}$ century, especially its last quarter, was characterized by unprecedented elevation of international law authority. The factors of this development focuse on globalization, which determines new features not only in the world system, but also in the internal life of the states. Globalization represents the unity of the rights and interests of mankind, since survival can only be achieved through joint efforts. Globalization opens up unprecedented opportunities for the prosperity of mankind and, at the same time, conceals important angers, therefore it is necessary to seize opportunities, appearing in general interest and to prevent negative consequences. Life increasingly demands the creation of a new world law order, that would ensure the survival and further progress of mankind. The crucial common interests of states and peoples should be at the basis of this new world order. The correlation of national and common interests is changing. Though some governments some times continue to be guided by narrow national interests, in opposition to general ones. But, without ensuring the latter one can not guarantee the first.

As a result of the dynamic practice of a number of agreed issues settlement, in such areas, as human rights, environment, high technologies, natural resources development, healthcare etc., there was a radical increase in normative material, mainly contractual sources of international law. At the same time, the latter gained not only a new content, but also a fundamentally new status. Since nowadays the most important norms of international law are enshrined in treaties, then the interpretation of the treaties became extremely important for the practice of international law ${ }^{1}$.

\footnotetext{
${ }^{1}$ Karvatska S. The status of international treaties determination in national law of Ukraine: contemporary challenges and prospects. Scientific achievements of countries of Europe in the field of legal science : Collective monograph. Riga : Izdevnieciba "Baltija Publishing”, 2018. P. 141-159.
} 


\section{The interpretation of an international treaty is the process of establishing the true content of the treaty}

Legal interpretation generally includes a contractual interpretation, constitutional interpretation, normative interpretation and contractual interaction. Contractual interaction is an important element of judicial or quasi judicial process to clarify and determine the rights and obligations between the parties to the treaty, by giving due importance to its term or provision based on fixed interpretation rules. In other words, since a treaty interpretation is part of the dispute settlement mechanism, essentially it is a process, but at the same time, a method based on determined interpretation rules. In order to understand, what is the essence of international treaties legal interpretation, it is necessary to define the characteristic features, without which it is impossible to function. The interpretation of a treaty has the following characteristics inherent to legal interpretation: 1) the appropriate legal process is usually carried out in international proceedings (for example, international judicial or quasi - judicial dispute resolution process); 2) the translator, as a rule, is an international judge or arbitrator in such proceedings; 3) the interpreted object is a contractual provision or term; 4) the purpose of the interpretation is to find out the meaning of an indefinite or contradictory term or provision, and also to attach meaning to such a term to be applied in an international dispute, in order to determine the rights and obligations of the parties; 5) the rules, on the basis of which the interpreter must interpret the treaty, are the provisions of the Vienna Convention on the Law Treaties (which are already codified by international standards of treaty interpretation) or, possibly, developed by judicial practice ${ }^{2}$.

Consequently, the key difference between the interpretation of international treaties and other legal interpretations is that the interpretation rules it uses are provided for by the Convention on the Law of international treaties (VCLT) and developed by international jurisprudence.

Interpretation of an international treaty is essentially the process of establishing the true value of a contract. The VCLT rules on the interpretation of contracts should rather describe the process of interpretation it self, than determine and evaluate all the necessary structural elements of the interpretation. In addition to international treaty interpretation, as the researchers note, the rules and principles of interpretation itself need to be interpreted, particularly those enshrined in the Vienna Convention. Panos Merkouris draws attention to this fact, and notes, that the courts sometimes interpreted customary rules of interpretation, that is, interpreted an interpretation rule itself ${ }^{3}$. Other

\footnotetext{
${ }^{2}$ Chang-fa Lo. Treaty Interpretation Under the Vienna Convention on the Law of Treaties. A New Round of Codification. Springer Nature Singapore. 2017. P. 6.

${ }^{3}$ Panos Merkouris. Interpreting the Customary Rules on Interpretation in International Community. Law Review. 2017. № 19. P. 126.
} 
scholars, for example, Christian Djeffal also pay attention to the problem of interpreting the rules on interpretation ${ }^{4}$.

General rules of interpretation are contained in art. 31 of the Vienna Convention on the Law of Treaties from 1969: "The treaty must be interpreted conscientiously in accordance with usual meaning to be given to the terms of the contract in their context, as well as in the light of the object and purposes of the contract" (item 1, art. 31). For the purposes of treaty interpretation, the term "context", together with the preamble and annexes, includes any agreement or document relating to the treaty, drawn up as a result of the conclusion of the contract (item 2, art. 31). In addition, any subsequent agreement between the parties regarding the interpretation or application of the treaty, subsequent practice of treaty application, establishing the participants' consent in relation to its interpretation, as well as any relevant rules of international law, applicable in relations between the parties (it. 3, art. 31). Article 32 of the Vienna Convention on certain international treaties from 1969reveals the notion of additional interpretation means. Among them preparatory materials (fr. travaux préparatoires), the circumstances of the treaty conclusion. Additional means of interpretation are used to confirm the value, given to the terms of the contract in their context or to determine the meaning if the interpretation according to art. 31 remains ambiguous or obscure, or leads to obviously absurd or foolish results 5 .

Article 31 on the establishment of the so-called general rule of interpretation, formulates universally accepted principles on the elements and means of the treaty interpretation. These principles are the result of international judicial and arbitration practice, they are universal customary rules, and discretionary according to their legal nature and character, but not mandatory. If such an interpretation is always aimed at clarifying the intentions of the parties, it can do so only to the extent, where this intention has found an adequate expression in the text of the treaty. And, vice versa, the wording of the contract in textual approach, according to art. 31, should playa major role in the interpretation, as it is believed to be the true expression of the parties' intentions. As an example, we can cite the decision of the International Court of Justice in the case "Serbia and Montenegro v. Belgium", in which the Court has noted, that the interpretation should be based "primarily on the text of the treaty"

\footnotetext{
${ }^{4}$ Djeffal Christian. Static and Evolutive Treaty Interpretation: A Functional Reconstruction. Cambridge University Press, 2016. 2 January.

${ }^{5}$ Vienna Convention on the Law of Treaties (with annex). Concluded at Vienna on 23 May 1969. URL: https://treaties.un.org/pages/ViewDetailsIII.aspx?src=TREATY\&mtdsg_no=XXIII$1 \&$ chapter=23\&Temp=mtdsg3\&clang=_en (дата звернення: 06.02.2019).

${ }^{6}$ Legality of Use of Force (Serbia and Montenegro v. Belgium) (Preliminary Objections). 2004. ICJ Report 279, Para 100.
} 
Thus, the purpose of interpretation is to establish the intention of the contract, that is, the intention to understand the true meaning of the contract, and not the intention of the parties, that are different from it.

It is significant to note, that in addition to the text of the agreement, an important meaning for the interpretation has item 3 , article 31 , which takes into consideration further developments and agreements between the parties, and practice of the contract use. Article 31 contains "general rule" of the contract interpretation. The common regulations mean the fact, that the provision contains a single rule in item 1 , and its three main elements are - the wording, context, object and purpose, and the guiding principle of conscientiousness is an integral part of this rule, and should be used in one combined operation. Items 2 and 3 of article 31 indicate what is understood by "context" and, thus, are closely related to paragraph 1, since it lists what is "included" in the context, whereas item 3 , instead of designating other elements of the context, enumerates the tools used with the context. However, regardless of such a different wording, both paragraphs are intended to include the elements of interpretation, outlined in this document, into general rule, contained in item 1. Paragraph 4 of article 31 , contains an exception to item 1 for cases, where the parties have agreed, even implicitly, to replace the usual meaning of the term, contained in the contract, by special meaning ${ }^{7}$.

It has been generally recognized, that the provisions on treaty interpretation, contained in articles 31 and 32, reflect an already existing international law. For many years, the International Court of Justice has applied the rules of interpretation, set out in the Convention, as a codified practice for every treaty it has got. In the 1991 decision on the arbitral decree from July 31, 1989, Guinea Bissau v. Senegal, the Court noted, that the data reflected in articles 31 and 32 of the Vienna Convention on the Law of Treaties, may be regarded in many respects as an existing international law codification ${ }^{8}$.

The justification for this provision can be found in subsequent court practice. The International Court of Justice position about the Vienna rules of interpretation, being universally binding without any distinction, as normal international law, is supported by other international courts, such as the ECHR, the EU and dispute resolution organs. Finally, normal character of the Vienna rules found expression in the very treaty practice. Thus, if the rules set out in articles 31-33 reflect universal customs, they can, in principle, apply to all treaties, not used within the scope of the Convention. This applies, firstly, to agreements, concluded before the Convention came into force (1980), and, secondly, to treaties between the states, which are not parties to the Convention,

\footnotetext{
${ }^{7}$ Vienna Convention on the Law of Treaties (with annex). Concluded at Vienna on 23 May 1969. URL: https://treaties.un.org/pages/ViewDetailsIII.aspx?src=TREATY\&mtdsg_no=XXIII1\&chapter $=23 \&$ Temp $=$ mtdsg3\&clang=_en (дата звернення: 06.02.2019).

${ }^{8}$ ICJ Arbitral Award (Guinea-Bissau v Senegal). 1991. ICJ Report 53. Para 48.
} 
recognized also by third states which are not parties to the Convention as well. For example, the United States or France: diplomatic practice of the US administration, as well as most of the US jurisprudence, reflect the view that articles $31-33$ of the VCL Texpress obligatory norms ${ }^{9}$.

Since interpretation is an indispensable transaction in the application and implementation of treaties, the problem of treaty interpretation is part of international law, as long as the agreements are concluded between the subjects of international law. One of the first known attempts to implement the codification of the rules on treaties was made under the auspices of the Harvard Law School, and in $1935^{10}$ a draft of the Harvard Convention on the Law of Treaties, an interpretation, as well as detailed commentary analysing legal literature and case law on this subject were published. Its interpretive provision (art. 19) was based on a rigorous teleological approach, since it paid particular attention to the achievement of "general purpose of the treaty". To determine this objective, it was necessary to define "historic basis of the contract", "circumstances during the time of conclusion of the contract", "subsequent behavior of the parties" in the agreement application and "conditions prevailing at the time of interpretation."

In accordance with the UN Charter, the International Court of Justice in the first years has developed its methods of treaty interpretation, but at the same time, expanding and clarifying the basic principles. In his analysis, G. Fitzmaurice gave a number of basic case-law practice of the Court in $1950^{\mathrm{s} 11}$ : according to the principle of reality or textuality, the treaties must be interpreted in accordance with their actual texts. This tendency of normal value advantages of the contract can be found in several earlier cases of the Court ${ }^{12}$. The principle of effectiveness, according to which contracts should be interpreted with reference to their declared or obvious objects and purposes, was used repeatedly by the Court, among the first cases - the Corfu Channel and damages cases.

The next principle, which the International Court clearly applied is its further practice, that is to say, the Court examined how the contract was actually applied by the parties or bodies authorized to do so. Another principle that G. Fitzmaurice suggested was the fact, that the terms of the contract should be interpreted in accordance with the value they had at the time of its conclusion. This principle was applied in the case of Morocco, which concerned the rights of the United States of America citizens in Morocco ${ }^{13}$. The case was instituted

\footnotetext{
${ }^{9}$ Criddle Byron. Review. Parliamentary History. 2004. Volume 23. Issue 3. P. 443-447.

${ }^{10}$ Research in International Law. Reporters 1932-1935. 1935. The American Journal of International Law. Vol. 29. P. 656-658.

${ }^{11}$ Fitzmaurice G. The Law and Procedure of the International Court of Justice 1951-4: Treaty Interpretation and Other Treaty Points 33 Brit. Y. B. Int'1 L. 203. 1957. P. 210-227

12 Asylum Case Summaries of Judgments, Advisory Opinions and Orders of the International Court of Justice. Judgment of 20 I November 1950. ICJ Report 266, 279.

${ }^{13}$ ICJ Rights of US Nationals in Morocco [1952] ICJ Report 176, 189.
} 
against the United States on the basis of a statement by the government of the French Republic. The judgment concerned a number of points. Firstly, with regard to licensing controls in the French zone of Morocco, the Court found that the United States, on the basis of its agreement with Morocco on September 16, 1836, have the right to a favorable economic regime. Secondly, on the basis of the same agreement, the United States have the right to exercise consular jurisdiction in all civil and criminal cases. At the same time, the Court (six votes in favor to five against) decided, that no agreement provided grounds for the US requirement to provide their citizens with tax immunity ${ }^{14}$.

The wording of these principles had a great effect on the subsequent work of the International Commission on the Law of Treaties. H. Waldock, the only one of the four Special Rapporteurs on the Law of Treaties considered them as an important source and introduced them in his work on this topic. Regulations on the treaty interpretation, which he proposed in 1964, were mostly in accordance with the principles set forth by Fitzmaurice. Waldock's project, art. 70, item 1, has combined four principles in one rule, such as common meaning, context, modernity and conscientiousness.

\section{Purpose and role of the Treaty Interpretation}

Speaking about the purpose and role of the interpretation, it is appropriate to cite a rather figurative statement by Ingo Venzke of the fact, that the interpretation looks like the discovery of the meanings and the disclosure of the law, it is similar to archeology, but it can often be seen, that international courts not only interpret the law in this sense, but also develop it in their practices ${ }^{15}$. Interpretation is nota secondary process, that is effective only when it is impossible to understand the common terms of the agreement, it is necessary because the corresponding words in their natural and ordinary meanings become meaning ful only in the context. In particular, as the Court noted in ICJ Second Admissions Case", to understand, whether the wording is clear or "makes sense", it is possible only in the process of interpretation. That is, when the subject of an international law, uses or observes a treaty it can do so only through a certain understanding of its terms, i.e. based on interpretation. As Georg Schwarzenberger rightly notes, any application of the contract, including its execution, implies previous conscious or subconscious treaty interpretation ${ }^{17}$.

\footnotetext{
${ }^{14}$ ICJ Rights of US Nationals in Morocco [1952] ICJ Report 176, 189.

${ }^{15}$ Ingo Venzke. The Role of International Courts as Interpreters and Developers of the Law: Working Out the Juris generative Practice of Interpretation. L.A. Int'l \& Comp. L. Rev. 99. 2011. P. 100.

${ }^{16}$ Competence of the General Assembly for the Admission of a State to the United Nations. 1950. ICJ Report 4, 8 .

${ }^{17}$ Schwarzenberger Georg. International Law as Applied by International Courts and Tribunals. Stevens \& Sons limited. London, 1968. P. 8.
} 
What is the need for an international treaty interpretation? Firstly, only during the interpretation it can be determined, whether the document is an agreement in general within the meaning of VCLT. Secondly, during the interpretation, it is possible to clarify the scope of application of the treaty: the subjects of the contract, the content of the contract and the time frame of its provisions' action. Thirdly, only in the process of interpretation one can determine the normative nature of the contract, that is, the rights and obligations of its parties, or a legal regime established by the treaty. Fourthly, it is only in the course of the interpretation, that it is possible to find out whether the contractual provisions are suitable so that they can be directly applied in contractual terms by the parties to the agreement.

Article 2.1 (a) the VCLT defines an "agreement" as "an international agreement enshrined by the states in writing, governed by international law, regardless of the fact whether it is embodied in one document, in two or more relevant documents, and regardless of its specific function" ${ }^{18}$. But, the practice shows that only those international documents, that impose at least "some" obligations for the parties, are concluded as treaties and treated as such. An optional international document is not considered an agreement, or, as a rule, is not accepted in the form of an agreement.

Consequently, there may exist no binding international documents, such as most of "declarations", and most of "guidelines" and "principles", adopted by members of international organizations or relevant parties. There may also be optional provisions in accordance with international treaties and within the framework of international treaties. With regard to such optional international documents or those not binding provisions stipulated by international treaties, the parties do not have a strict international obligation to implement them. For these optional documents and optional rules, "legal interpretation" is not an important element for their activity ${ }^{19}$.

However, for mandatory provisions of international treaties, it is important for the rights of the parties to be preserved and their obligations fulfilled in such a way, that contracts can perform their proper function. In order to safeguard the rights and fulfillment of obligations, as well as compliance with contractual rules, the majority of contracts have strict or "soft" procedures for settling disputes. Interpretation of an agreement is a very important part of the dispute settlement procedure (especially for more stringent dispute settlement

\footnotetext{
${ }^{18}$ Article 2.1 (a) Vienna Convention on the Law of Treaties (with annex). Concluded at Vienna on 23 May 1969. URL: https://treaties.un.org/pages/ViewDetailsIII.aspx?src=TREATY\&mtdsg_no=XXIII-1\&chapter= 23\&Temp=mtdsg3\&clang=_en (дата звернення: 06.02.2019).

${ }^{19}$ Chang-fa Lo. Treaty Interpretation Under the Vienna Convention on the Law of Treaties. A New Round of Codification. Springer Nature Singapore, 2017. P. 8.
} 
procedures $)^{20}$. Thus, treaty interpretation is an important element of international agreements mechanism, especially for their mandatory provisions.

As noted above, the first important feature for interpreting a contract is the fact, that treaty interpretation is an important element of international judicial and quasi-judicial proceedings. The essence of international legal proceedings is that: 1) decisions are based on certain substantive and procedural rules; 2) decisions are legally binding for the parties. In international legal proceedings, the judge is obligated to analyze the facts, interpret them, apply procedural rules and take decisions on the case. Therefore, the interpretation of a relevant provision or its term in a relevant agreement is an important part of an international judicial process ${ }^{21}$. Treaty interpretation is carried out by international judges or arbitrators, and in the context of the WTO, settlement of disputes is carried out by the appellate body. This is due to the fact, that these individuals, or bodies are judges, or quasi - judges. This differs from the interpretation of a constitutional provision or legal provision in the national context, which is usually carried out by national courts.

International treaty interpretation and internal legal interpretation (including constitutional and legislative interpretations)and have something that combines them. Thus, domestic courts in their practice should also interpret and apply international agreements to settle disputes, if such international agreements directly regulate legal relations, resolved by national courts. Domestic (national) courts conduct and interpret an international treaty, relying on the VCLT provisions.

In accordance with articles 1 and 2.1 (a) of the Vienna Convention on the Law of Treaties (VCLT) (including its contractual interpretation of part of articles 31 to 33) is applied to the agreements adopted by the states in writing. Thus, contractual interpretation, carried out according to the VCLT, consists in the interpretation of written agreements (including multilateral, regional and bilateral agreements). Other forms of international law, including customary international law and general principles of law, are not subjects to the rules of contractual interpretation.

But this does not mean, that there is no need for the interpretation of other forms of international law. An example of codified international rules, that require interaction is the VCLT itself. The Vienna Convention on the Law of Treaties (VCLT) is a set of codified rules, reflecting generally accepted international law. For those states that have ratified the Vienna Convention on the Law of Treaties (VCLT), it has the character of an agreement, as defined by the VCLT articles 1 and 2.1 (a) about the law of the International Treaties

\footnotetext{
${ }^{20}$ Chang-fa Lo. Treaty Interpretation Under the Vienna Convention on the Law of Treaties. A New Round of Codification. Springer Nature Singapore, 2017. P. 8.

${ }^{21}$ Chang-fa Lo. Treaty Interpretation Under the Vienna Convention on the Law of Treaties. A New Round of Codification. Springer Nature Singapore, 2017. P. 8.
} 
(VCLT). For those other countries that have not ratified the VCLT, the rules contained there, as before, have the character of customary international rules. The necessity of interpretation is also applied to articles 31-33 of the Vienna Convention (VCLT), which govern the interpretation of treaties. So, when we discuss the meaning and application of articles 31-33 of the Vienna Convention on the Law of Treaties (VCLT), we are in fact involved in correct interpretation of these provisions.

\section{What is the key difference between interpreting international treaties and other legal interpretations?}

As mentioned above, the fundamental distinction between day-to-day interpretation and legal interpretation is that legal interpretation should be based on certain rules. And fundamental difference between the treaty interpretation and other legal interpretations is, that the treaty interpretation is based on certain predetermined international rules of interpretation, while other legal interpretations (including normative interpretation, constitutional interpretation and contractual interpretation) may be based on internal legislative acts.

The unifying characteristic feature of treaty interpretation and other legal interpretations is the fact, that their functions are to provide for proper meaning of the term, being interpreted. And they differ not only in methods, used in the process of interpretation, but also in the vector and results.

According to Plato, "the legislator is a writer, and the judge is a reader". Consequently, judges should read the law in order to cover the normative basis for resolving the dispute. Therefore, their work involves defining the appropriate norm (to know what to read) and properly interpret the norm (to read it correctly to ensure that the controversial parties can understand its meaning) for the final resolution of the dispute. In internal context, the judges should read a domestic law (and not create a national law) not only for the dispute, but also for other persons within the same jurisdiction. In international context, an international judge should read the relevant treaty (and not create a contractual norm) not only for those controversial states to resolve their controversial dispute, but also for other states that are governed by the same treaty, in order to understand how to implement their contractual obligations. Consequently, from the point of view of the role played by the national court and the international judge, these judicial institutions are related.

Having said that, it should be noted, that a lot of time the judge can not avoid the creation of certain rules through interpretive activities to fill the gap and resolve the dispute. The question is, what should be the limitation, in order to avoid unwanted activation of judicial activity.

There are many types of legal documents that are of different nature. Some legal documents (statute and constitution) are internal norms. And others (for example, 
bilateral, regional and multilateral treaties) are international norms, regulating relevant issues outside of a particular jurisdiction. Regardless of their characteristic, they all need to be interpreted, when there is a dispute over the "correct meaning" of the term or provisions of the documents. General problems of interpreting these documents are quite similar. They are mainly interpreted by the courts: regulatory interpretation is carried by local judges or courts of arbitration. Constitutional interpretation - by constitutional courts or higher courts of respective jurisdictions. In contractual interpretation, interpreters also are judges or arbitral tribunals. Interpretation of the treaty is mainly carried out by international courts (such as the International Court of Justice and the Panel of judges or the WTO Appellate Body, which interpret for the dispute settlement body).

The interpretation of all types of legal documents always begins with the texts of such documents. Thus, the wording of the text is the starting point of all interpreters, be it interpretation of the provisions in the Statute, Constitution, in an agreement or an international agreement. However, there are differences in the role of a context: what should be the context, whether one should follow the developer's intention, and what is the extent to which the object and purpose of legal documents must also affect the interpretation. Another point, which should be emphasized, is that contractual interpretation, legislative interpretation and constitutional interpretation are basically legal questions, and decisions can be appealed to a higher court.

As we have noted before, all legal interpretations depend on certain established rules. But unlike the interpretation of an international agreement, governed by international rules established under the Vienna Convention on the Law of Treaties, there are no uniform rules of interpretation for legal and constitutional interpretations. Different legal systems have their own rules and principles of legislative or constitutional interpretation, which are provided by laws or developed in court system. However, there are some generally accepted rules or principles regarding these interpretations.

Another important aspect regarding normative and constitutional interpretations concerns their possible international limitations. In fact, international standards can influence such interpretations in many ways, although there are no comprehensive international rules, that would restrict such interpretations. The example of international norms, relating to legislative, constitutional and contractual interpretations, is that the interpretation of national law provisions may become a specific appealing measure. For example, when the interpretation of national law Trade provisions in national court is consistent with the requirement of a "unified, impartial and reasonable method". Next, let's assume that the text formulation of the trade law is unclear, as to whether the legislation on trade provides for a special state measure, restricting international trade. Interpretation becomes an integral part of the law on trade, 
which necessarily restricts international trade. Consequently, the interpretation, together with the explanation of the law, may become a disputed measure. For the same reason, the Constitutional Court interpretation of constitutional provisions, restricting international trade, may be challenged by other members of the $\mathrm{WTO}^{22}$.

Depending on the type and nature of the law being interpreted, the rules and methods for interpreting the law can vary significantly. As mentioned above, there are no international common rules of standard-setting interpretation for all jurisdictions. Therefore, the first general rule for normative interpretation is to rely on the textual formulation and interpretation of the text, based on its usual meaning. This mainly requires a literal interpretation of the provision.

International treaties also have different categories. Except for those treaties, dealing with or regulating civil and private matters, there are also treaties relating to criminal cases (such as the United Nations Convention against transnational organized crime, which provides for criminal liability for participation in an organized criminal group, money laundering, obtained from crime, and corruption practices) and other agreements. All of them fall under the same rules of interpretation, as contained in the Vienna Convention on the Law of Treaties, which does not distinguish between the specificity and categories of interpreted treaties. However, for the interpretation of the treaty, the intentions of the developer, reflected in the preparatory work, are secondary means. It is used only for confirmation of the meaning, arising from the application of article 31 of the Vienna Convention on the Law of Treaties, or to determine the meaning, when the interpretation, in accordance with article 31, leaves the meaning ambiguous, unclear, or leads to a result which is manifestly absurd or unreasonable. In contractual interpretation, the context may be very broad to refer not only to other parts of the treaty, its preamble, annexes, and other treaties. But in legal interpretation, the method of contextual or system interpretation is not used at all ${ }^{23}$.

Constitutional interpretation is similar, and, at the same time, different from statutory interpretation. Both of them are guided by the usual meaning of the text, and the context of norms. Previous court decisions are also important both for legislative interpretation, and for constitutional interpretation, because they play the part of obligatory source. First, social, political and economic consequences may affect constitutional interpretation, or its consequences. Since constitution is the highest norm in the jurisdiction, its activities will affect not only the legal system and practice there, but also the basic rights of the people. Second, natural law and certain social values may serve as a reference point for

\footnotetext{
${ }^{22}$ Chang-fa Lo. Treaty Interpretation Under the Vienna Convention on the Law of Treaties. A New Round of Codification. Springer Nature Singapore, 2017. P. 14.

${ }^{23}$ Martorana V. A Guide to Contract Interpretation. 2014. URL: https://files.reedsmith.com/files/uploads/ miscellany/A_Guide_to_Contract_Interpretation_July_2014_.pdf (дата звернення: 08.02.2019)/
} 
constitutional interpretation. And since the bulk of the constitutions of most countries seek to ensure the protection of fundamental rights and human dignity, the result of constitutional provision interpretation will be in line with the relevant human rights treaties.

Third, the related problem is the desire to provide a real constitution through constitutional interpretation. If new norms can not be introduced into the constitutional system through interpretations, it will transform the "old age" of the constitution into its "obsoleteness".

Fourth, it is possible to adopt an "evolutive interpretation", in order to give a new meaning to the old constitutional provision. This is especially important, if there is a new content of fundamental rights, which are developed or recognized internationally (for example, a treaty recognizing a new type of human rights). Fifth, in constitutional interpretation the intentions of the legislator are important, but not critical. The Constitution is not just a legal document, it is a political document. Subjects of interpretation can not deliberately change the intentions of the constitution developers. Sixth, in interpreting a constitutional provision, it may be very important to balance various factors and competing interests $^{24}$.

\section{CONCLUSIONS}

International treaty interpretation is a process of establishing the true value of an agreement. However, as a treaty interpretation is part of judicial or quasijudicial proceedings, and this process must be independent, then the same activity on international treaty interpretation should be a legal process, not a political process.

Despite the fact that many international disputes arise exclusively from an unclear fact, a large number of international disputes arises from a fuzzy or uncertain provision or a term of the contract, from its incompleteness, or even from its contradictory provisions. For a fuzzy provision of a contract, or a term, the judge must correctly understand its meaning before applying the provision. Even if a contractual provision or a term is clear to one of the parties, the other party may propose a different understanding of this provision, so the disputed provisional ways requires appropriate interpretation measures.

The key difference between international treaty interpretation and other legal interpretations lies in the fact, that the rules of interpretation that it applies, are provided by the Convention on the Law of Treaties (VCLT) and developed by international jurisprudence. Another important feature in the interpretation of an international treaty, is that such an interpretation is an important element of international judicial and quasi-judicial proceedings. The common characteristic

\footnotetext{
${ }^{24}$ Chang-fa Lo. Treaty Interpretation Under the Vienna Convention on the Law of Treaties. A New Round of Codification. Springer Nature Singapore. 2017. P. 27-28.
} 
of international treaty interpretation and other legal interpretations is that their functions are to provide the proper meaning of the term being interpreted. But they differ not only in the methods, used in the process of interpretation, but also in the direction and results.

On the other hand, to achieve the goal of predictability of treaty interpretations and appropriate interpretation of an international treaty, the rules of interpretation should not be too general. The problem is that the current VCLT interpretation rules (under articles 31-33)are too general. Of course, there may be different views on the need for another round of codification of the rules for interpreting treaties. The content that will be codified, also may be debatable, but the transparency, and predictability of treaty interpretation should be more important.

\section{SUMMARY}

Nowadays the most important norms of international law are enshrined in the treaties, that is why the interpretation of treaties has become extremely important for the practice of international law. Interpretation of an international treaty is a process of establishing the true value of an agreement. The key difference of international treaty interpretation and other legal interpretations lies in the fact that the rules of interpretation, which it uses, are provided for by the Convention on the law of international treaties (VCLT) and developed by international jurisprudence. An other important feature in the interpretation of international treaties is that such an interpretation is an important element of international judicial and quasi-judicial proceedings. The common characteristic of international treaty interpretation and other legal interpretations, is that their functions are to provide the term being interpreted, with proper value. They differ not only in the methods, used in the process of interpretation, but also in the direction and results. At this stage, there may be different views on the need for a further round of codification of the rules of treaty interpretation. The content, that can be codified, also may be debatable, however, the transparency and predictability of treaty interpretation should be more important.

\section{REFERENCES}

1. Asylum Case Summaries of Judgments, Advisory Opinions and Orders of the International Court of Justice. Judgment of 20 I November. 1950. ICJ Report 266, 279.

2. Djeffal Christian. Static and Evolutive Treaty Interpretation: A Functional Reconstruction. Cambridge University Press, 2016. 2 January.

3. Fitzmaurice G. The Law and Procedure of the International Court of Justice 1951-4: Treaty Interpretation and Other Treaty Points. Brit. Y.B. Int'l L. 203. 1957. P. 210-227. URL: https://heinonline.org/HOL/LandingPage? handle=hein.journals/byrint33 (дата звернення: 08.02.2019). 
4. Gardiner R. Treaty Interpretation. Oxford University Press, 2015. 576 p.

5. ICJ Arbitral Award (Guinea-Bissau v. Senegal). 1991. ICJ Report 53.

6. ICJ Rightsof US Nationals in Morocco.1952. ICJ Report 176, 189.

7. Karvatska S. The status of international treaties determination in national law of Ukraine: contemporary challenges and prospects. Scientific achievements of countries of Europe in the field of legal science : Collective monograph. Riga : Izdevnieciba "Baltija Publishing", 2018. P. 141-159.

8. Legality of Use of Force (Serbia and Montenegro v. Belgium) (Preliminary Objections). 2004. ICJ Report 279. Para 100.

9. Lo Chang-fa. Treaty Interpretation Under the Vienna Convention on the Law of Treaties. A New Round of Codification. Springer Nature Singapore, 2017. $361 \mathrm{p}$.

10.Martorana V. A Guide to Contract Interpretation. 2014. URL: https://files.reedsmith.com/files/uploads/miscellany/A_Guide_to_Contract_Inter pretation_July_2014_.pdf (дата звернення: 08.02.2019)

11.Panos Merkouris. Interpreting the Customary Rules on Interpretation in International Community Law Review. 2017. 19. 126 p.

12.Venzke Ingo. The Role of International Courts as Interpreters and Developers of the Law: Working Out the Juris generative Practice of Interpretation, 34 Loy. L.A. Int'1\&Comp. L. Rev. 99. 2011. P. 100. Para 48.

13.Schwarzenberger Georg. International Law as Applied by International Courts and Tribunals. Stevens\& Sonslimited. London. 1968. 881 p.

14.Vienna Convention on the Law of Treaties (with annex). Concluded at Vienna on 23 May 1969. URL: https://treaties.un.org/pages/ ViewDetailsIII.aspx $?$ src $=$ TREATY\&mtdsg_no $=$ XXIII$1 \&$ chapter $=23 \&$ Temp=mtdsg3\&clang=_en (дата звернення: 06.02.2019).

15.Waldock Humphrey. General course on public international law. Volume 106. Collected Courses of the Hague Academy of International Law, The Hague Academy of International Law. URL: http://dx.doi.org/10.1163/18758096_ pplrdc_ej.9789028614321.001_251 (дата звернення: 08.02.2019).

\section{Information about author:} Karvatska S. B.,

Ph.d. in Law, Doctoral Candidate at the Institute of International Relations of Taras Shevchenko National University of Kyiv, 36/1, Yuriia Illenka str., Kyiv, 04119, Ukraine, Associate Professor of Department of Human Rights Law Faculty Yuriy Fedkovych Chernivtsi National University, 2, Kotsubynskogo Str., Chernivtsi, 58012, Ukraine 